Article

\title{
Factors Affecting Farmers' Access to Formal and Informal Credit: Evidence from Rural Afghanistan
}

\author{
Masaood Moahid ${ }^{1,2, *}$ and Keshav Lall Maharjan ${ }^{1}$ \\ 1 Graduate School of International Development and Cooperation, Hiroshima University, Hiroshima 739-8529, \\ Japan; mkeshav@hiroshima-u.ac.jp \\ 2 Faculty of Agriculture, Nangarhar University, Jalalabad City, Nangarhar 2601, Afghanistan \\ * Correspondence: masaoodnufa@gmail.com
}

Received: 26 December 2019; Accepted: 4 February 2020; Published: 10 February 2020

check for updates

\begin{abstract}
Adequate access to credit is necessary for the sustainable development of agriculture. This study uses a double hurdle model to investigate what affects farming households' credit participation and amount, and a Probit model to find out credit constraints. For this purpose, the data from a survey of 292 farming households in Afghanistan was utilized. The study finds that households obtain credit for their agricultural activities from various formal and informal sources. The results of the double hurdle model reveal that the financial activities of the households were positively determined by crop diversity, education, number of adults in a household, size of land, and access to extension. Non-agricultural income decreases the likelihood of participation. The results of the analysis of credit constraints indicate that formal credit did not help small-scale and remoter farming households; however, these households relied on informal credit, especially when they faced income shock. Furthermore, religious belief increased the chances of avoiding formal credit but not informal credit. It is suggested that formal credit should be expanded to rural areas, especially to small-scale farming households. Policy makers should also consider increasing access to extension. Formal financial institutions should provide Sharia-compliant credit, which increases the confidence level of households in using formal credit in Afghanistan.
\end{abstract}

Keywords: formal credit; informal credit; participation; amount of credit; credit constraints; double hurdle model; probit model

\section{Introduction}

Afghanistan is a least developed country. Farmers' access to credit is critical in the country because agriculture has a significant role in its economy as it makes up 23 percent of the gross domestic product (GDP). Some 70 percent of the population inhabits in rural areas in the country, and agriculture is the mainstay for their livelihood. Furthermore, the agriculture sector provides income to 44 percent of the households in the country [1]. However, the productivity in the agriculture sector is very low; for example, the yield of wheat, which is the major and staple crop of the country, is only $2210 \mathrm{~kg}$ per hectare [2], substantially less compared to other countries.

Moreover, the subsistence type of agriculture dominates the agriculture sector of Afghanistan. More than half of the households produce mainly for their consumption [3]. They barely market their produce, which causes them to remain cash-starved. Farmers' ability to purchase farm inputs and make farm-related investments remain low in the country, and as a consequence, they are not able to invest in more productive technology. They continue with traditionally practiced subsistence agriculture. Therefore, the development of the agriculture sector is an indispensable policy challenge for the government of Afghanistan. 
To develop agriculture, the relevance of utilizing improved inputs such as fertilizer, improved seed, and equipment cannot be overlooked [4]. According to Omobowale et al. [5], the low use of improved inputs and technology is the main factor of low productivity in agriculture. The suboptimal use of inputs and improved technologies restricts the sustainable development of agriculture in Afghanistan, according to Saleem and Raouf [6]. Credit is an essential facilitator for the sustainable development of agriculture [7]. Access to improved inputs mostly depends on access to credit. Access to credit influences technology adoption; thus, it is decidedly linked with agricultural productivity [8]. Diagne et al. [9] describe that access to credit increases households' wellbeing because it increases the households' capability of access to inputs at the time they are seasonally cash-starved, which finally increases labor productivity, which is necessary for development.

As in other developing countries, the credit sector in Afghanistan is instinctively divided into formal and informal subsectors. Formal credit in Afghanistan comes from the banks and non-bank financial institutions. After the onset of the new government in 2002 and the enacting of the new banking law in 2003, several initiatives by the private sector, NGOs, and development partners were taken to improve access to credit in rural areas. Twelve banks are operating in Afghanistan, consisting of three state banks, seven private banks, and two branches of foreign banks [10]. These banks exist in large cities or provincial towns. They are, therefore, operating at a higher distance from the farmers in rural areas. To minimize the risk of default, the banks mostly ask for collateral, i.e., registered land documents, and other valuable assets. Most of their clients, however, need to have confirmation of collateral approved by the government. Non-bank financial institutions include microfinance institutions and credit unions. They provide both individual and group credit to their customers. They also extend credit to borrowers who are unable to provide collateral. However, despite the efforts, a large number of farmers have been left out. As a result, participation in formal credit is meager. In 2018, only 3.1\% of farming households participated in formal credit [11].

The low participation in formal credit may have many reasons. Some reasons may endure on farmers' side; for example, low education, low resource endowment, and societal norms, while some may lay on the supply-side, such as the sense that lending to farming is unsafe [12]. If the supply of formal credit is not adequate, the informal credit market instinctively comes into the foreground [13]. As per [14], 42 percent of the households in rural areas took informal credit. Diagne [9] noted, "understanding how nonmarket informal institutions serve the financial need of households ... is valuable for sustainable and market-oriented financial institutions ... " (p. 3). Therefore, in the context of Afghanistan, analyzing the existing informal credit is also necessary, which will help to suggest policies for sustainable formal financial arrangements. In Afghanistan, informal credit has two features-cost-free credit and transactional credit. Friends, wealthy villagers, and relatives provide cost-free credit, which is usually a small amount with a short repayment period. Transactional credit is obtained from input suppliers, traders, wholesalers, money lenders, and land mortgagees, which usually includes a high-interest rate and lack transparency.

The policymakers in Afghanistan need to take effective measures to decrease dependence on informal credit and improve access to formal credit for farmers in Afghanistan. Therefore, they should recognize who participates in formal and informal credit, how many loans they acquire, what prevents farmers from using the formal credit market, and by what these are affected. Therefore, to generate policy-relevant insights for the expansion of effective, sustainable, and inclusive financial institutions for farmers in Afghanistan, it is essential to know the factors affecting participation in credit, the amount of credit obtained, and the credit constraints.

This study contributes to the current literature in three ways. Firstly, to the extent of our knowledge, no empirical study investigates what affects the financial activities of farmers in Afghanistan. The available few studies on credit in Afghanistan have not focused on the socio-economic aspects of the farmers that may affect farmers' participation in credit, the size of credit, and the credit constraints. The current literature on other countries shows that socio-economic factors influence the financial activities of rural households [15-18]. However, the direction of the influence of the factors differs 
from case to case. Viewing the social and cultural differences, the finding from studies on a different context may not suit Afghanistan. Hence, a key motivation in our paper is that there is limited knowledge about what affects farmers' financial activities in the context of Afghanistan. Secondly, the extant studies have not empirically analyzed some relevant societal norms, such as religious behavior regarding the utilization of credit for agricultural purposes. Islam prohibits interest-based credit [19]. Thus, it is imperative to investigate the religious aspects that are presumed to affect access to credit in a traditionalistic and Muslim majority country like Afghanistan. Thirdly, this study considers informal credit, which is taken for agricultural purposes. The literature on informal credit obtained for agricultural purposes is scanty in Afghanistan and elsewhere. The current studies are not specifically focused on agricultural informal credit. The analysis of factors that affect obtaining informal credit for different purposes may not be true for the informal credit obtained specifically for agricultural purposes.

Given this, the objectives of this study are three-fold. First, to analyze factors affecting farmers' participation in formal and informal credit sources in Afghanistan. Second, to analyze the factors that affect the amount of credit obtained from formal and informal sources. Third, to analyze the factors affecting the credit constraints in formal and informal agricultural credit markets in Afghanistan. The findings lead to a piece of better knowledge about the existing formal and informal credit arrangements and the policy measures, which will contribute to the expansion of effective and sustainable formal credit to farmers.

\section{Methodology}

\subsection{Data}

We gathered the data utilized in this study through a cross-sectional personal interview survey that was carried out in the purposefully chosen three districts, i.e., the Balkh, Paghman, and Behsood districts. We selected these districts because both formal and informal credit sources are available to the farmers in these districts. Besides, the principal source of livelihood in all these districts is agriculture and all these districts are categorized under rural areas [20]. Ninety-six formal credit users, 94 informal credit users, and 102 non-credit users' households were randomly selected to make up a total of 292 households. ${ }^{1}$ A semi-structured questionnaire was utilized for the interviews. In addition to obtaining information regarding credit, information about socio-economic attributes, such as age, farm size, and education, were collected. The households were those who obtained formal or informal credit mainly for their agricultural activities from July 2016 to August 2018 and those who did not take any credit in the period above.

\subsection{Analytical Methods}

\subsubsection{Participation and Amount of Credit}

When statistically modeling credit participation, it is necessary to address two essential and different elements-households' participation in credit and their decision for the size of the credit (or how much to borrow) conditioned on participation. Barslund and Tarp [15] describe that households take credit if they anticipate an uptick in utility, and they avoid it contrariwise. If a household takes credit for productive purposes, the variables related to the "optimal investment" defines the credit amount. They state that the above structure steers to a double hurdle model. Several other researchers have also used this model for similar situations [21-23]. Therefore, adopting a double hurdle model for this study, we pretend that households make two decisions in obtaining credit, and a set of explanatory variables defines each of them. In order to witness a particular level of the credit amount, two separate hurdles must be passed: participation in credit and the decision for the amount of credit. A distinct 
latent variable is used to model each decision process, where a Probit model first portrays participation in credit, and a Tobit model determines the amount of credit. Thus,

$$
\begin{gathered}
\mathrm{y}^{*}{ }_{11}=\alpha w_{i}+v_{i} \\
\mathrm{y}^{*}{ }_{\mathrm{i} 2}=\beta x_{i}+u_{i} \\
\mathrm{y}_{\mathrm{i}}=\beta x_{i}+u_{i}
\end{gathered}
$$

$v_{i} \sim \mathrm{N}(0,1)$ and $u_{i} \sim \mathrm{N}\left(0, \sigma^{2}\right)$.

Equation (1) is called the "first hurdle," because it is the first step in the two-step process that produces observed credit participation in survey data. $\mathrm{y}^{*}{ }_{\mathrm{i} 1}$ is a latent variable describing the households' participation in the credit; $\alpha$ is the vector of the parameters to be estimated, and $w_{i}$ is the set of regressors that affect participation decision. Formally, Equation (1) implies that individual $i$ will participate in credit if $v i>-\alpha w_{i}$, and the probability of observing individual $i$ participating in credit is $P\left(v i>-\alpha w_{i}\right)$. Equation (2) shows the credit amount obtained by the households. Where $\mathrm{y}^{*} \mathrm{i} 2$ is a latent variable indicating how much credit is obtained, $\beta$ is a vector of unobserved parameters to be estimated, and $x_{i}$ is the set of regressors explaining the individual $i$ 's decision about the size of credit. $u_{i}$ is an unobserved random variable grabbing all factors other than $x_{i}$ that influence the decision about the amount of credit. Equation (2) is called the "second hurdle" in the two-step model, which describes the process in which households obtained the credit amount. In Equation (3), the observed dependent variable $\left(\mathrm{y}_{\mathrm{i}}\right)$ is (1) if $\left(y^{*}{ }_{i 1}>0\right)$ and $\left(y^{*}{ }_{i 2}>0\right),\left(y_{i}\right)$ is (0) otherwise.

Other alternatives to the double hurdle model are the Tobit model and the Heckman selection model. The Tobit model relies on the corner solution and excludes the participation decision by households. The Heckman selection model only allows censoring in the participation or in the first hurdle [24]. Once households participated, it is presumed that they have a positive amount of credit. The double hurdle model relaxes the assumption that the participation decision is unnecessary. It allows for censoring at each step of the model. If both $u_{i}$ and $v_{i}$ are normally distributed and the independent random variable is with zero mean and constant variance, the likelihood function for the double hurdle model is:

$$
L=\Pi_{1}\left(\mathrm{P} v_{i}>-\alpha w_{i}\right) \mathrm{P}\left(u_{i}>-\beta x_{i}\right) f\left(y^{*}{ }_{i 2} / u_{i}>-\beta x_{i}\right) \cdot \Pi_{0}\left(1-\mathrm{P}\left(v_{i}>-\alpha w_{i}\right) \mathrm{P}\left(u_{i}>-\beta x_{i}\right)\right)
$$

\subsubsection{Credit Constraints}

Credit constraints is a binary variable where being credit constrained takes a value of one if a household is credit constrained, and zero otherwise. Thus, to estimate the probability of credit constraints, the Probit model was utilized, which is written as follows:

$$
\begin{gathered}
\qquad C_{i}^{*}=\gamma x_{i}+e_{i} \\
C_{i}=\gamma x_{i}+e_{i} \\
\text { Request credit }\left\{\begin{array}{c}
\text { Formal credit }(1, \text { constrained; } 0, \text { unconstrained }) \\
\text { Informal credit }(1, \text { constrained; } 0, \text { unconstrained })
\end{array}\right.
\end{gathered}
$$

$C_{i}^{*}$ is a binary variable that shows if a household is credit constrained or not and $x_{i}$ is the set of regressors affecting credit constraints. $\gamma$ is the vector of the parameters to be estimated and $e_{i}$ is the error term. The observed dependent variable $C_{i}$ is (1) if $\left(C_{i}^{*}>0\right)$, and is (0) otherwise.

To analyze how the regressors affect dependent variables, marginal effects were estimated in both models. For the continuous explanatory variables, these marginal effects are used to calculate elasticities at the sample mean. For dummy variables, they are used to calculate percentage changes in the dependent variable when the variable changes from zero to one, other variables at their sample mean [23]. 


\subsection{Description of the Variables Used in the Models}

We describe the variables and their expected impact on credit participation, amount, and constraints as follows.

The average amounts of credit obtained from formal and informal credit sources were 49,090 $\mathrm{AFN}^{2}$ and 39,355 AFN, respectively.

It is presumed that the productive resources, i.e., farm size, number of adults (which is the proxy for labor), and livestock positively affect both participation in credit and the amount of credit. Agricultural land increases the probability of obtaining credit $[25,26]$. The total farm size is assumed to increase credit needs resulting from the demand for agricultural inputs. Additionally, agricultural land is considered to be prominent collateral to obtain formal credit in rural areas. Hence, farm size should positively affect participation and the amount of credit. The number of adults in a household often indicates labor endowment for households' economic endeavors. The availability of labour to a household decreases the credit risk [27]. Therefore, its influence is also expected to be positive.

The coefficients of education and farming experience ${ }^{3}$ of the household head are likewise expected to have positive signs. More exceptional capacity and human capital should positively affect investment possibilities. Similarly, access to extension, membership in an association, and land entitlement should have a positive impact. Membership in associations is expected to increase participation in credit, as the farmers who are members of any producers' association or cooperative are more connected and aware. Additionally, some formal financial institutions also regard membership in an association as mitigating the nonpayment risk.

Crop diversity increases the use of costly inputs; thus, it is anticipated to increase participation in credit and the size of the credit. Initial expectations about the sign of the variables capturing income from the sources other than farming are deemed not to be always in one direction, so we incorporate these as control variables without visible prior signs. Non-agricultural income on the one side increases confidence of households, as it can be a source of finance to ensure repayment, thus it raises the probability of participating in credit and the credit amount [28]. However, on the other side, it may overcome households' credit needs because such households may be capable of meeting their financing inadequacies without going for credit. We also add a dummy for income shocks as a proxy to denote unexpected loss due to low harvest, market failure, or any other unexpected occurrence in the past two years without a prior expected sign.

It is anticipated that the coefficient of the distance from the cities is negative. The financial institutions in Afghanistan are located in the cities. Proximity to the financial institution is a vital factor affecting participation in credit [29-31]. However, the distance from cities may not affect informal credit. Farm size and education may increase the probability of participation and the size of credit in the initial stage. However, with further increase, after a certain point, the probability may change with these variables. Higher education and ample land size may reduce the need for credit. Therefore, to capture this kind of effect, the squared terms for these variables were included in the model.

It is relevant to consider the religious aspects of credit while analyzing the factors of participation in financial services in the context of Afghanistan. More religious households are assumed to be less likely to participate in interest-based credit since conventional interest-based transactions are not allowed in Islam-and the religion of all the interviewed households was Islam. Asking directly about religiosity is socially inappropriate and sometimes provocative. Therefore, we included a dummy for religious education ${ }^{4}$ as a proxy in an attempt to capture the religious behavior of the household head regarding credit.

The same set of independent variables has been used in both the double hurdle model and Probit model. However, the prior expectation about the effects of the variables may differ in each model. Credit constrained households in this study are the rejected, partially lent, and those households who needed money but did not acquire it because of unawareness, religious belief, or any other reason. Doan and Tuyen [18] have regarded the latter ones as "discouraged" credit constrained households. Those who could borrow a sufficient amount or who did not borrow because of having adequate 
resources are regarded as credit unconstrained. According to Doan et al. [29], "the factors affecting credit constraints are components of creditworthiness or lending criteria and are often used by the lenders to evaluate their clients' creditworthiness in order to sort out potential borrowers" (p. 7). The extant literature shows assets, education, distance, and the number of adults to be significant factors of credit constraints [15,18,32,33]. Lin et al. [34] found households' non-agricultural income and education to be negatively affecting credit constraints while investigating the effects of demographic factors on credit constraints. According to Sekyi et al. [35], the number of children in a household increases the likelihood of credit constraints as having more children increases households' expenditure . In this study we expect that religious belief also positively influences credit constraints. Table 1 describes the variables used in the models.

Table 1. Variable descriptions.

\begin{tabular}{|c|c|}
\hline Variables & Description \\
\hline \multicolumn{2}{|l|}{ Continuous } \\
\hline Education & Years of formal education \\
\hline Farm size & Size of cultivable land in Jeribs ${ }^{5}$ \\
\hline Dependency ratio & Dependency ratio of a household \\
\hline No. of adults & Number of adults in a household who are able to work \\
\hline Crop diversity & Crop diversity index $(1-\mathrm{HHI})^{6}$ \\
\hline Distance & Distance from the nearest city in $\mathrm{km}$ \\
\hline Experience & Farming experience of the household head (years) \\
\hline Farm size squared & Squared term of farm size \\
\hline Education squared & Squared term of education \\
\hline \multicolumn{2}{|l|}{ Discrete } \\
\hline Extension & $\begin{array}{l}1=\text { Have access to agricultural extension services } \\
0=\text { Do not have access }\end{array}$ \\
\hline Non-agricultural income & $\begin{array}{l}1=\text { Household receive non-agricultural income } \\
0=\text { Do not receive }\end{array}$ \\
\hline Membership in association & $\begin{array}{l}1=\text { Have membership in any farmers' association } \\
0=\text { Do not have }\end{array}$ \\
\hline Registered land documents & $\begin{array}{l}1=\text { Have registered land documents which can work as collateral for obtaining credit } \\
0=\text { Do not have }\end{array}$ \\
\hline Livestock & $\begin{array}{l}1=\text { Household raises animals beside crop production } \\
0=\text { Do not raise }\end{array}$ \\
\hline Income shock & $\begin{array}{l}1=\text { Household has had faced crop failure, market failure, or any other unexpected } \\
\text { loss in the last two years } \\
0=\text { Have not faced }\end{array}$ \\
\hline Religious education & $\begin{array}{l}1=\text { Household head has religious education } \\
0=\text { Does not have }\end{array}$ \\
\hline
\end{tabular}

\section{Results and Discussion}

The results of the analysis are revealed and discussed in the subsequent sub-sections. We start by giving an overview of the household characteristics in the study area. We compare the descriptive statistics by whether or not the households obtained formal or informal credit. Next, we display a summary of credit constrained and unconstrained households. Lastly, the results of the models are revealed and discussed.

\subsection{Socio-Economic Characteristics of the Households}

Tables 2 and 3 summarize and compare the descriptive statistics of the households. In terms of education, informal credit users had, on average, a lower education level (6.38 years) than the 
other groups. Literacy rate is generally low in Afghanistan. In the whole sample, 39.8 percent of the household heads never attended any formal education. This could be attributed to the long-lasting war and instability in the country after the Soviet occupation in 1980. Although most of the households are smallholders, the size is more substantial in the case of formal credit users (6.38 Jeribs) compared to the other groups. The average cultivable farm size for informal credit users was 5.12 Jeribs. Total landholding has been viewed as a crucial determinant of household financial activities. Small farmers are always in need of money at the start of a season to purchase necessary farming inputs and to smooth consumption unto the next harvest. Because of this, farmers resort to formal and informal credit [36]. The average distance from the cities for the formal category is $10.1 \mathrm{~km}$, higher in the case of non-credit users $(12.41 \mathrm{~km})$. The average farming experience of non-users was 23.87 years higher compared to the formal (22.0 years), and informal groups (22.59 years). About 43.43 percent of non-users were receiving non-agricultural income compared to 26.2 percent for formal credit users, and 35.02 percent for informal credit users. This may, on the one hand, indicate that non-users receive adequate income and thus have no need to borrow. However, on the other hand, for non-user households, due to the low investment, farming may be less profitable. Thus, to support their families, they depend on off-farm activities. Therefore, households with more extra income are less likely to borrow. Yet, this does not suggest that access to credit is not a problem for the non-users.

Another critical item to point out is the crop diversity. The crop diversity index for the formal credit users is higher (0.48), compared to the non-users (0.33), and informal credit users (0.44). Of the formal credit users, 12.12 percent were members of a farmers' association, compared to an average of 4.04 percent for non-credit users. The percentage of households that suffered income shock in the case of informal credit users was 18.72 percent, compared to the formal credit users $(18.94 \%)$ and non-users $(15.84 \%)$. Finally, 22.16 percent of the heads of the households in the formal category received religious education. The percentage of religious education was higher in the case of non-users (30.69\%).

Table 2. Descriptive statistics of the variables (continuous).

\begin{tabular}{|c|c|c|c|c|c|c|c|c|c|}
\hline \multirow{2}{*}{ Variables } & \multicolumn{3}{|c|}{$\begin{array}{c}\text { Non-Users } \\
\text { (102) }\end{array}$} & \multicolumn{3}{|c|}{$\begin{array}{l}\text { Informal } \\
(94)\end{array}$} & \multicolumn{3}{|c|}{$\begin{array}{c}\text { Formal } \\
\quad(96)\end{array}$} \\
\hline & Mean & Max & Min & Mean & Max & Min & Mean & Max & Min \\
\hline Education (years) & $\begin{array}{c}6.65 \\
(5.85)\end{array}$ & 19 & 0 & $\begin{array}{c}6.38 \\
(5.83)\end{array}$ & 17 & 0 & $\begin{array}{l}7.14 \\
(5.9)\end{array}$ & 17 & 0 \\
\hline Farm size (Jeribs) & $\begin{array}{c}5.61 \\
(4.87)\end{array}$ & 32 & 0.8 & $\begin{array}{c}5.12 \\
(3.32)\end{array}$ & 17 & 1 & $\begin{array}{c}6.38 \\
(4.32)\end{array}$ & 19 & 0.8 \\
\hline Number of adults (Persons) & $\begin{array}{l}5.37 \\
(2.80)\end{array}$ & 1 & 14 & $\begin{array}{l}4.16 \\
(2.75)\end{array}$ & 1 & 12 & $\begin{array}{c}6.17 \\
(3.38)\end{array}$ & 1 & 12 \\
\hline Dependency ratio & $\begin{array}{c}4.35 \\
(2.24) \\
\end{array}$ & 10 & 1 & $\begin{array}{c}4.43 \\
(2.74) \\
\end{array}$ & 10 & 0 & $\begin{array}{c}4.61 \\
(2.83) \\
\end{array}$ & 7.5 & 1 \\
\hline Distance from the city $(\mathrm{km})$ & $\begin{array}{l}12.41 \\
(4.13)\end{array}$ & 23 & 5 & $\begin{array}{l}11.27 \\
(3.63)\end{array}$ & 29 & 5 & $\begin{array}{c}10.1 \\
(3.57)\end{array}$ & 19 & 5 \\
\hline Crop diversity index (1-HHI) & $\begin{array}{c}0.33 \\
(0.23)\end{array}$ & 0.7 & 0 & $\begin{array}{c}0.44 \\
(0.19)\end{array}$ & 0.9 & 0 & $\begin{array}{c}0.48 \\
(0.133)\end{array}$ & 0.8 & 0 \\
\hline Farming experience (years) & $\begin{array}{c}23.87 \\
(13.12)\end{array}$ & 55 & 5 & $\begin{array}{c}22.59 \\
(11.86)\end{array}$ & 49 & 5 & $\begin{array}{c}22.0 \\
(11.37)\end{array}$ & 50 & 3 \\
\hline
\end{tabular}


Table 3. Descriptive statistics of the variables (categorical).

\begin{tabular}{lccc}
\hline \multicolumn{1}{c}{ Variables } & $\begin{array}{c}\text { Non-Users } \\
\mathbf{( 1 0 2 )}\end{array}$ & $\begin{array}{c}\text { Informal } \\
\mathbf{( 9 4 )}\end{array}$ & $\begin{array}{c}\text { Formal } \\
\text { (96) }\end{array}$ \\
\hline Access to extension (\% access) & 69.70 & 59.60 & 78.80 \\
Non-agricultural income (\% yes) & 43.43 & 35.02 & 26.20 \\
Membership in farmers' association (\%yes) & 4.04 & 8.08 & 12.12 \\
Registered land documents (\% yes) & 43.43 & 36.36 & 47.40 \\
Livestock (\% yes) & 84.85 & 67.68 & 71.70 \\
Income shock (\% yes) & 15.84 & 18.72 & 18.94 \\
Religious education (\% yes) & 30.69 & 22.02 & 22.16 \\
\hline
\end{tabular}

\subsection{Credit Constrained and Unconstrained Households}

Analyzing credit constraints helps to understand what blocks farmers' access to credit from the supply side [18]. According to Lin [16], "credit constraint arises when there is a mismatch between the household's credit demand and access to credit" (p. 3). The percentage of credit constrained and unconstrained households is shown in Table 4. The credit constrained households make 71.23 percent of the whole sample, higher compared to unconstrained households (30.14\%). Partially lent household in case of informal credit users makes 20.55 percent and in formal credit users 19.52 percent. Only 4.39 percent of households did not participate in credit as they reported sufficient resources and did not need credit. 25 percent of the whole sample needed money but did not apply. Among 190 formal and informal credit user households, 75 were lent a sufficient amount (the amount they applied for).

Table 4. Credit constrained and unconstrained households.

\begin{tabular}{lcc}
\hline \multicolumn{1}{c}{ Categories } & $\begin{array}{c}\text { No. of } \\
\text { Households }\end{array}$ & $\begin{array}{c}\text { Percentage (\%) of Total } \\
\text { Households }\end{array}$ \\
\hline Total number of households & 292 & 100 \\
Households who did not want to borrow & 13 & 4.45 \\
$\quad$ Sufficient capital, no need credit (a) & 74 & 25.34 \\
$\quad$ Need credit, but did not apply (b) & & \\
Households that needed capital (and applied) & 15 & 5.14 \\
Were not lent any money (denied) & 9 & 3.08 \\
$\quad$ Formal (c) & 6 & 2.05 \\
$\quad$ Informal (d) & 119 & 40.75 \\
Were lent an amount which is less than what households wanted & 57 & 19.52 \\
$\quad$ Formal (e) & 60 & 20.55 \\
$\quad$ Informal (f) & 75 & 25.68 \\
Was lent fully & 39 & 13.36 \\
$\quad$ Formal (g) & 34 & 11.64 \\
Informal (h) & & \\
Credit Participation in the Past Two Years & 190 & 65.07 \\
Borrowers & 96 & 32.88 \\
$\quad$ Formal (e and g) & 94 & 32.19 \\
$\quad$ Informal (f and h) & 102 & 34.93 \\
Non-borrowers (a, b, c and d) & & \\
Credit constraints & 206 & 71.23 \\
Constrained (b, c, d, e and f) & 86 & 30.14 \\
Unconstrained (a, g and h) & &
\end{tabular}

Low repayment capacity, i.e., low income and not having sufficient collateral or a guarantor, were the main reasons for the households whose formal credit was rejected. The lenders' fear of default due to the low profitability of the farm was the main reason for those who applied for informal credit sources and were denied. Among the quantity rationed households, the formal credit users were lent partially due to the lack of sufficient collateral or a guarantor, low repayment capacity, and the limit set by some formal financial institutions for lending to farmers. Low repayment capacity was the main reason provided by informal credit users for being quantity rationed. The reasons provided by the 
households who needed money to invest in their farms but did not participate in any credit programs were lack of information, religious belief, lack of guarantor/collateral, complicated procedure, distance, high-interest rate, and the fear of being rejected.

\subsection{Factors Affecting Participation in Formal and Informal Credit and the Amount of Credit}

Table 5 reveals the results of the double hurdle model estimated for formal and informal categories. The findings of the first hurdle report that for the formal category, the probability of participation in credit significantly increases with crop diversity and access to the extension services. Crop diversity is also significant in economic terms. In Afghanistan, crop diversity implies adding vegetables, fruits, and other high-value crops (e.g., saffron) along with wheat, corn, and rice, which are the food crops [37]. These are cost-intensive crops, which increase the demand for inputs and, thus, credit. Households in the country with a lower crop diversity index mostly grow food crops. Extension services in Afghanistan are rendered by the Ministry of Agriculture, Irrigation, and Livestock, donor organizations, some companies, and some formal financial institutions. Along with providing other necessary agricultural education, they also offer information about obtaining credit from formal financial institutions. The sign of the number of adults also turns out to be significant and positive at a 10 percent significance level. The number of adults in a household indicates labor endowment for household economic endeavors; therefore, it increases the demand for credit. According to Shah et al. [31], households with more adults are likely to participate more in formal credit as it increases their confidence to repay the credit.

However, the probability of participation in formal credit significantly decreases with receiving income from sources other than agriculture, income shock, and living at a higher distance from the cities. Income from other sources such as remittances and off-farm jobs may offset the need for credit. Distance is also significantly and negatively affecting participation in formal credit. Formal financial institutions in Afghanistan are located in the cities. They mostly target household in nearby areas that are easily accessible to them. Similarly, households who have faced income shock were less likely to participate in formal credit. Having suffered from income shock in the past two years decreases the probability of participating in formal credit by 48.6 percent.

Similar to the formal credit, the likelihood of participation in informal credit significantly increases with crop diversity and decreases with non-agricultural income. However, the coefficient of receiving non-agricultural income in the case of informal credit is economically higher than in case of formal credit. Receiving non-agricultural income decreases the probability of participation in informal credit by 112.6 percent. This finding is consistent with Lin et al. [34], who found that non-agricultural jobs decrease the demand for informal credit in the rural areas of China.

Nevertheless, the direction of the influence of the distance to cities and income shock on participation in credit differs by the type of credit. The probability of farmers' participation in formal credit is significantly and negatively affected by the distance of farmers from the cities. However, distance to the cities positively affects participation in informal credit at a 10 percent significance level. Similarly, the households who encountered income shock in the past two years were more likely to participate in informal credit. However, as discussed earlier, income shock reduces the possibility of participation in formal credit. This implies a strong social relationship and helps among farming households in the rural areas in Afghanistan. Most of the informal credit was collateral-free and mainly based on relationship or interpersonal trust. The social relationship increases with the more rural and farther areas [18]. Therefore, the households located farther from the cities have a higher probability of obtaining informal credit. In the case of informal credit users, the sign of dependency ratio was positive and significant, which shows that as the number of dependents in a household increases relative to economically active members, the demand for informal credit increases. Households with more dependents are not able to save money; thus, they need credit. However, formal financial institutions consider them as less creditworthy; therefore, they rely on informal credit. In the case of informal credit users, the signs of access to extension and experience were negative but significant only at the 10 percent significance level. 
Table 5. Factors affecting participation in formal credit and the amount of credit.

\begin{tabular}{|c|c|c|c|c|c|c|c|c|}
\hline \multirow[t]{2}{*}{ Independent Variables } & \multicolumn{2}{|c|}{$\begin{array}{c}\text { Formal Credit } \\
(\text { Participation = 1) }\end{array}$} & \multicolumn{2}{|c|}{$\begin{array}{l}\text { Formal Credit } \\
\text { Amount (log) }\end{array}$} & \multicolumn{2}{|c|}{$\begin{array}{c}\text { Informal Credit } \\
\text { (Participation = 1) }\end{array}$} & \multicolumn{2}{|c|}{$\begin{array}{l}\text { Informal Credit } \\
\text { Amount (log) }\end{array}$} \\
\hline & ME & SE & ME & SE & ME & SE & ME & SE \\
\hline Education (years) & 0.515 & 0.065 & 0.007 & 0.037 & 0.006 & 0.067 & -0.019 & 0.063 \\
\hline Farm size (Jeribs) & 0.038 & 0.067 & $0.205^{* * *}$ & 0.064 & -0.031 & 0.109 & 0.043 & 0.103 \\
\hline Dependency ratio & 0.144 & 0.112 & 0.063 & 0.057 & $0.326^{* *}$ & 0.095 & -0.007 & 0.086 \\
\hline Number of adults (Persons) & $0.080 *$ & 0.049 & $-0.054^{* *}$ & 0.023 & 0.018 & 0.041 & -0.010 & 0.037 \\
\hline Access to Extension ( 1 if have access, 0 otherwise) & $0.650 * *$ & 0.283 & -0.111 & 0.183 & $-0.410 *$ & 0.239 & 0.152 & 0.214 \\
\hline Non-agricultural income ( 1 if have, 0 otherwise) & -0.449 * & 0.251 & -0.133 & 0.145 & $-1.126^{* *}$ & 0.234 & -0.450 * & 0.303 \\
\hline Membership in association ( 1 if have, 0 otherwise) & 0.732 & 0.421 & -0.156 & 0.194 & $0.920 *$ & 0.483 & -0.043 & 0.416 \\
\hline Registered documents of land ( 1 have, 0 otherwise) & 0.337 & 0.215 & -0.084 & 0.114 & 0.037 & 0.221 & -0.188 & 0.205 \\
\hline Crop diversity $(1-\mathrm{HH})$ & $2.331 * * *$ & 0.656 & -1.976 & 0.449 & $2.432 * * *$ & 0.603 & 0.221 & 0.591 \\
\hline Experience (years) & 0.006 & 0.011 & -0.002 & 0.005 & $-0.015 *$ & 0.009 & 0.005 & 0.009 \\
\hline Livestock ( 1 raising livestock, 0 otherwise) & -0.056 & 0.260 & $-0.304^{* *}$ & 0.136 & -0.020 & 0.255 & 0.364 & 0.246 \\
\hline Farm size squared & -0.002 & 0.003 & $-0.013^{* * *}$ & 0.004 & -0.004 & 0.007 & -0.001 & 0.007 \\
\hline Education Squared & -0.001 & 0.004 & 0.000 & 0.003 & -0.001 & 0.005 & 0.001 & 0.004 \\
\hline Income shock & $-0.585 *$ & 0.318 & 0.175 & 0.210 & $0.486^{* *}$ & 0.253 & -0.130 & 0.229 \\
\hline Distance $(\mathrm{km})$ & $-0.097^{* * *}$ & 0.030 & $-0.031 *$ & 0.018 & $0.058 *$ & 0.029 & -0.038 & 0.025 \\
\hline Religious education ( 1 have, 0 otherwise) & -0.357 & 0.273 & -0.215 & 0.163 & 0246 & 0.233 & $0.393 *$ & 0.213 \\
\hline Number of observations & 198 & & & & 194 & & & \\
\hline LR chi2 & 125.44 & & & & 89.05 & & & \\
\hline Prob > chi 2 & 0.000 & & & & 0.000 & & & \\
\hline Pseudo R2 & 0.26 & & & & 0.17 & & & \\
\hline Log likelihood & -178.03 & & & & -222.83 & & & \\
\hline
\end{tabular}

Note: marginal effects are calculated at sample means. Standard errors are robust. ${ }^{* * *},{ }^{* *}$ and ${ }^{*}$ denote statistical significance at the $1 \%, 5 \%$, and $10 \%$ levels, respectively. 
The factors affecting the amount of credit, as calculated in the second step of the double hurdle model, are also illustrated in Table 5. The results show that given participation in credit, the likelihood of the amount of credit obtained from formal sources significantly increases with farm size. Having one more unit of farmland increases the probability of the household credit amount from the formal sources by 20.5 percent. However, the sign of the squared term for farm size is negative and significant, which indicates an inverted-U shape effect on the probability of the amount obtained from formal credit. The farmers in our sample are generally smallholders. Their amount of credit increases with the increase in farm size; however, with further increments in the farm size after a certain point, the probability of the amount of credit decreases. The farmers with extra-large farm sizes may offset some of their capital needs from their higher total income.

Contrary to the expected signs, the households who raise livestock tend to borrow a lesser amount. This is presumably because households opt to sell their animals at the time they need money. Furthermore, the number of adults in the household and the distance to the city also significantly reduce the likelihood of the amount of credit from formal sources.

In the case of informal credit users, the likelihood of the amount of credit significantly decreases with non-agricultural income. Receiving non-agricultural income reduces the probability of the amount obtained from informal credit by 45 percent.

\subsection{The Factors Affecting Credit Constraints}

The results of the Probit model are shown in Table 6. In the case of formal credit, most of the significant coefficients are aligned with the results of participation. According to Doan et al. [29], such incident shows the soundness of the results. We find that the higher the education, farm size, and non-agricultural income, the lower the probability of being credit constrained in the case of formal credit users. However, distance from the city increases the likelihood of credit constraints. These variables are policy-relevant, as these are more linked to the credit market, especially in the case of formal credit. The formal financial institutions consider these aspects of the borrowing households while sanctioning credit.

Table 6. Factors affecting credit constraints.

\begin{tabular}{lcccc}
\hline \multirow{2}{*}{\multicolumn{1}{c}{ Independent Variables }} & \multicolumn{2}{c}{$\begin{array}{c}\text { Formal Credit } \\
\text { (Constrained } \mathbf{~ 1 ) ~}\end{array}$} & \multicolumn{2}{c}{$\begin{array}{c}\text { Informal Credit } \\
\text { (Constrained = 1) }\end{array}$} \\
\cline { 2 - 5 } & ME & SE & ME & SE \\
\hline Education (years) & $-0.047^{* * *}$ & 0.017 & $-0.033^{*}$ & 0.018 \\
Farm size (Jeribs) & $-0.063^{* *}$ & 0.028 & -0.008 & 0.018 \\
Dependency ratio & -0.040 & 0.028 & $-0.060^{* * *}$ & 0.022 \\
Family labor & 0.001 & 0.014 & -0.006 & 0.010 \\
Access to extension (1 if have access, 0 otherwise) & -0.093 & 0.072 & 0.037 & 0.063 \\
Non-agricultural income (1 if have, 0 otherwise) & $-0.119^{*}$ & 0.067 & 0.010 & 0.065 \\
Membership in associations & 0.059 & 0.100 & 0.001 & 0.121 \\
Registered documents of land (1 have, 0 otherwise) & -0.035 & 0.058 & 0.071 & 0.058 \\
Crop diversity (1-HH) & 0.128 & 0.172 & -0.199 & 0.140 \\
Experience (years) & -0.001 & 0.003 & -0.001 & 0.002 \\
Raising livestock (1 raising livestock, 0 otherwise) & 0.012 & 0.073 & -0.021 & 0.063 \\
Farm size squared & $0.003^{*}$ & 0.001 & 0.001 & 0.001 \\
Education squared & $0.002^{* *}$ & 0.001 & 0.002 & 0.001 \\
Income shock (1 faced, 0 otherwise) & -0.030 & 0.079 & $-0.126^{*}$ & 0.073 \\
Distance (km) & $0.028^{* * *}$ & 0.009 & 0.008 & 0.009 \\
Religious education (1 have, 0 otherwise) & $0.122 *$ & 0.065 & 0.075 & 0.061 \\
Number of observations & 198 & & 194 & \\
Wald chi2 & 33.47 & & 26.95 & \\
Prob > chi2 & 0.014 & & 0.008 & \\
Pseudo R2 & 0.17 & & 0.120 & \\
Log likelihood & -95.04 & & -92.22 & \\
\hline
\end{tabular}

Note: marginal effects are calculated at sample means. Standard errors are robust. ${ }^{* * *},{ }^{* *}$ and ${ }^{*}$ denote statistical significance at the $1 \%, 5 \%$, and $10 \%$ levels, respectively. 
Based on this, we can say that formal financial institutions exclude households with lesser farm size, education, and those who do not receive non-agricultural income. Likewise, households in remoter areas are also excluded. However, the coefficients of the squared terms for both farm size and education are positive and significant. This shows that with the further increase of these two variables after specific points, the likelihood of credit constraint increases. This could be because farmers with extra-large farm size and higher education need a large amount of credit. Some financial institutions in the study area had a certain upper limit for the credit they were disbursing to the farmers.

Religious education significantly increases the likelihood of credit constraints. To have religious education increases the probability of credit constraint by 12.2 percent, which shows that households' heads with more religious belief tend to avoid formal credit. However, the coefficient is not significant in the case of informal credit. Formal credit was mainly a conventional interest-based credit, not complying with Islam. The credit of only 11.58 percent of the households who received formal credit was complying with the Islamic doctrines, which is also called Sharia-compliant credit. The remaining 88.42 percent of households obtained the conventional interest-based credit. Islamic finance has been newly introduced to Afghanistan. It was included in the banking law of Afghanistan in 2015 [10]. Some formal financial institutions, especially the credit unions, have added it to their financial products list; however, the formal credit market generally provides conventional interest-based credit. Among the informal credit users without credit taken by 6.38 percent of households from moneylenders, other types were not considered forbidden in Islam. Karlan et al. [38] documents, "in Muslim majority countries financial inclusion rates are particularly low, especially among low-income populations" (p. 5). The farmers in the study area were mostly low-income people. This shows that although farmers need credit to invest in their farming, due to religious belief they tend to avoid interest-based credit.

In the case of informal credit users, the probability of credit constraint significantly decreases with income shock and dependency ratio. Informal credit was mostly provided based on mutual cooperation and relationship, which has helped households in harsh times. This indicates that a strong network of assistance and personal relationship exist among the households in the rural areas of Afghanistan. According to Klijin [39], informal credit helps farmers in Afghanistan at the time of emergencies. However, participation in informal credit also generates some disadvantages. It causes personal dependence and even inferiority for the borrower [40]. In the case of default, it creates conflict between the borrowers and lenders. Farmers in the study area opined that sometimes they are compelled to sell their harvest at low prices to repay the credit. Furthermore, informal credit users complained about the short repayment period and higher implicit interest rate. In the study area, the average interest rate was 32.46 percent for the transactional credit taken from informal sources, substantially higher than in the case of formal credit with an average of 18.2 percent. According to [41], informal credit is not based on proper structures and lacks transparency. Rajeev and Deb [42] found that informal credit is harmful as it put rural people in the vicious circle of debt. The sign of the coefficient of education in the case of informal credit users was also negative; however, its coefficient turns out to be significant only at a 10 percent significant level.

\section{Conclusions and Policy Implications}

Farmers' access to formal and informal credit in Afghanistan is barely investigated. This paper is written to fill this gap using data from 296 farming households in Afghanistan. It uses a double hurdle model to analyze the factors that affect participation in credit and the amount of credit obtained from formal and informal credit sources by agricultural households, and a Probit model to analyze the credit constraints in formal and informal credit markets.

Formal and informal credit coexist in the study area, which is obtained from various sources. However, formal credit institutions exist in the cities, and their coverage is low.

The results show that at the household level, the participation in formal credit significantly increases with crop diversity, access to extension services, and the number of adults in a household. It decreases with income shock, non-agricultural income, and distance from the cities. On the other 
hand, the likelihood of participation in informal credit increases with crop diversity, income shock, and decreases with non-agricultural income. The probability of credit amount from formal sources mainly increases with farm size and decreases with raising livestock, the number of adults, and distance to the cities. The likelihood of the amount of credit in case of informal credit decreases with non-agricultural income.

The analysis of the credit constraints shows that in the formal credit market, the probability of credit constraint decreases with education, farm size, and non-agricultural income, and increases with distance and religious education. Dependency ratio, income shock, and education reduce the likelihood of credit constraints in the informal credit market.

Based on the results drawn from the analysis we can conclude: first, households with higher crop diversity tend to participate more in both formal and informal credit markets. Second, the formal financial institutions in Afghanistan exclude remoter farming households and poorer households (in terms of farm size and not receiving non-agricultural income); therefore, these households rely on informal credit. Third, informal credit lenders, unlike their formal credit counterparts, lend to households when they are going through a harsh time, which shows a strong social network and personal relationship in the rural areas of Afghanistan. Finally, Household heads with religious education are more likely to avoid formal credit.

Formal financial arrangements can support the sustainable growth of agriculture [43]. Therefore, it is suggested that the coverage of formal credit should be increased through establishing branches and expanding the staff of the financial institutions in the remoter rural areas. There is a need to design innovative credit programs targeting specifically poor and small farmers. At the same time, government and financial institutions should stimulate demand for formal credit through awareness building, financial education, and extension services. This study also affirms the conclusion of Lin et al. [34] that formal financial institutions should enhance the size of credit through "innovative credit models".

Last but not least, formal financial credit should be shaped considering the local customs and religious belief, i.e., credit should comply with Sharia (Islamic doctrines), which is an alternative to conventional banking. Many studies recommend credit designed based on Islamic banking for agriculture in Muslim countries [36]. It has recently developed and coexists along with traditional banking in all Muslim and some non-Muslim countries. Sharia-compliant financial products often have the same goal as conventional products but change parts of the operational details to avoid interest (usury).

\section{Weaknesses and Future Research}

This research only analyzes the factors which affect credit participation, amount, and constraints in formal and informal credit markets in Afghanistan. It would be of great interest to know the impact of formal and informal credit on farm productivity and income, and the consequences of credit constraints on farm income. This study also does not analyze the repayment behavior of the farming households, i.e., how many farmers have paid the credit on time, and how many have defaulted. Future researches should consider these aspects of the credit markets in Afghanistan.

\section{Notes}

1 The number of households who obtained both formal and informal credit in the specified period was only seven, not eligible for being a separate group in the models. Therefore, we included these households in the other credit user groups based on the amount of credit.

2 One US dollar was equal to 69.30 Afghanis on 2018/08/20.

3 Studies considered age as a proxy for experience. However, due to the migration of people from the rural areas of Afghanistan during the conflicts between 1980 and 2001, age may not be the proxy of experience in Afghanistan, so it is wise to control for farming experience rather that age. 
4 Religious education includes the interpretation of the Quran and Hadith (the sayings of the Prophet Mohammad PBUH) and Islamic law. Religious education is mostly obtained in Madrassas, which are the religious seminaries, and Mosques in Afghanistan.

5 Jerib is the unit of land measurement in Afghanistan. One jerib is equal to 0.2 hectares.

6 We have used the Herfindahl Hirschman Index (HHI) to assess the magnitude of crop diversity. This index is the sum of squares of all (n) proportions (in our study, the sum of squares of all proportions of crops grown in a year). The value of "HHI" approaches one when there is complete specialization and zero when the number of crops is more revealing the highest diversity. In this study, the crop diversity index is (1-HHI), in which zero shows monocropping, and one stands for the highest diversity. $\left(\mathrm{CDI}=1-\mathrm{HHI}=1-\sum_{i=1}^{n} \mathrm{Pi}^{2}\right)$. See Biswas [44].

Author Contributions: M.M. and K.L.M. formulated the idea. M.M. conducted the household survey and contributed to the writing and formal analysis of the research. K.L.M. supervised the research and revised the manuscript. All authors have read and agreed to the published version of the manuscript.

Funding: This research did not receive any external funding.

Acknowledgments: We appreciate the Japan International Cooperation Agency (JICA) for facilitating Masaood Moahid a scholarship.

Conflicts of Interest: The authors declare no conflict of interest.

\section{References}

1. Central Statistics Organization. Afghanistan Living Conditions Survey 2016-17; Central Statistics Organization: Kabul, Afghanistan, 2017. Available online: https:/www.nsia.gov.af:8080/wp-content/uploads/2019/04/AMPI-2019-full-report-English-1.pdf (accessed on 20 July 2019).

2. Central Statistics Organization. 2019. Available online: https://www.nsia.gov.af:8080/wp-content/uploads/ 2019/11/Afghanistan-Statistical-Yearbook-2018-19_compressed_2.pdf (accessed on 15 September 2019).

3. World Bank. Unlocking the Potential of Agriculture for Afghanistan's Growth; World Bank: Washington, DC, USA, 2018. Available online: www.worldbank.org/en/country/afghanistan/publication/unlocking-potentialof-agriculture-for-afghanistan-growth (accessed on 21 September 2019).

4. Binswanger, H.P.; Khandker, S. The Impact of Formal Finance on the Rural Economy of India. J. Dev. Stud. 1995, 32, 2. [CrossRef]

5. Omobowalie, O.; Eprhraim, N.; Pender, D.; Phillips, D.; Kato, E. Trends and Drivers of Agricultureal Productivity in Nigeria; International Food Policy Research Institute: Washington, DC, USA, 2009; NSSP Report 1.

6. Saleem, S.; Raouf, M.E. Sustainable Agricultural Development and the Challenges Facing Agricultural Education in Afghanistan. J. Dev. Sustain. Agric. 2011, 6, 45-49.

7. Akinbode, S.O. Access to credit: Implication for Sustainable Rice production in Nigeria. J. Sustain. Dev. Afr. 2013, 15, 13-30.

8. Simtowe, F.; Bekele, S.; Menale, K.; Monyo, E.; Silim, S.; Muricho, G. Assessment of the Current Situation and Future Outlooks for the Groundnut Sub-Sector in Malawi; International Crops Research Institute for the Semi-Arid Tropics: Nairobi, Kenya, 2009.

9. Diagne, A.L.; Zeller, M.; Sharma, M. Empirical Measurement of Households' Access to Credit and Credit Constraints in Developing Countries: Methodological Issues and Evidence; Food Consumption and Nutrition Division (Fend) Discussion Paper 90; IFPRI: Washington, DC, USA, 2000. Available online: https://pdfs.semanticscholar.org/ 7b67/65562350afc6231a32153dfc552cf99fbc58.pdf (accessed on 7 July 2019).

10. DAB (Da Afghanistan Bank). Economic and Statistical Bulleten; DAB: Kabul, Afghanistan, 2019. Available online: https://dab.gov.af/sites/default/files/2019-10/Economic\%20Bulletin\%20for\%20Q2-2019\%20final.pdf (accessed on 10 December 2019).

11. MISFA (Microfinance Investment Facility for Afghanistan). Annual Report; MISFA: Kabul, Afghanistan, 2018. Available online: http://www.misfa.org.af/wp-data/uploads/2018/09/201889.pdf (accessed on 7 July 2019).

12. Weber, R. Is agricultural microcredit really more risky? Evidence from Tanzania. Agric. Financ. Rev. 2012, 72, 416-435. [CrossRef] 
13. Chaudhuri, S.; Gupta, M.R. Delayed formal credit, bribing and the informal credit market in agriculture: A theoretical analysis. J. Dev. Econ. 1996, 51, 433-449. [CrossRef]

14. NRVA. The National Risk and Vulnerability Assessment; Central Statistics Organization of Afghanistan: Kabul, Afghanistan, 2005. Available online: http://catalog.ihsn.org/index.php/catalog/934 (accessed on 24 September 2019).

15. Barslund, M.; Tarp, F. Formal and Informal Rural Credit in Four Provinces of Vietnam. J. Dev. Stud. 2008, 44, 485-503. [CrossRef]

16. Atieno, R. Formal and Informal Institutions' Lending Policies and Access to Credit by Small-Scale Enterprises in Kenya: An Empirical Assessment; AERC, Research Paper No. 111; African Economic Research Consortium: Nairobi, Kenya, 2001; ISBN 0002-1466. [CrossRef]

17. Saqib, S.E.; Ahmad, M.M.; Panezai, S. Landholding size and farmers' access to credit and its utilisation in Pakistan. Dev. Pract. 2016, 26, 1060-1071. [CrossRef]

18. Doan, T.; Tuyen, T.Q. Credit participation and constraints of the poor in peri-urban areas, vietnam: A micro-econometric analysis of a household survey. Argum. Oecon. 2015, 1, 34. [CrossRef]

19. Parto, S. Demand Assessment for Sharia-Based Financial Products Findings from Research in Herat, Jalalabad, Kabul, and Mazar-e Sharif; Afghanistan Public Policy Research: Kabul, Afghanistan, 2011. Available online: http://appro.org.af/wp-content/uploads/2017/03/137302015-Micro-Finance-in-Afghanistan-Adaptor-Fail.pdf (accessed on 12 November 2019).

20. National Statistical and Information Authority of Afghanistan. Statistical Yearbook of Afghanistan: 2018-2019; National Statistical and Information Authority of Afghanistan: Kabul, Afghanistan, 2019. Available online: https://www.nsia.gov.af:8080/wp-content/uploads/2019/11/Afghanistan-Statistical-Yearbook-201819_compressed.pdf (accessed on 11 November 2019).

21. Vuong, Q.D. Determinants of Household Access to Formal Credit in the Rural Areas of the Mekong Delta, Vietnam; MPRA Paper No, 38202; Department of Agricultural Economics, Ghent University of Belgium, Schools of Economics \& Business Administration, Cantho University: Cantho, Vietnam, 2012. Available online: http://mpraubuni-muenchende/38202/ (accessed on 8 December 2019).

22. Jacob, R.; Thomas, S.J.; Ephraim, C. Subsidies and Crowding Out: A Double-Hurdle Model of Fertilizer Demand in Malawi. Am. J. Agric. Econ. 2011, 93, 26-42. [CrossRef]

23. Newman, C.; Henchion, M.; Matthews, A. A double-hurdle model of Irish household expenditure on prepared meals. Appl. Econ. 2003, 35, 1053-1061. [CrossRef]

24. Brouhle, K.; Khanna, M. Determinants of participation versus consumption in the Nordic Swan eco-labeled market. Ecol. Econ. 2012, 73, 142-151. [CrossRef]

25. Binswanger, H.P.; Rosenzweig, M. Behavioral and material determinants of production relations in agriculture. J. Dev. Stud. 1989, 22, 503-539. [CrossRef]

26. Tang, S.; Zhengfei, G.; Songqing, J. Formal and Informal Credit Markets and Rural Credit Demand in China. Presented at the AAEA, CAES, and WAEA Joint Annual Meeting, Denver, CO, USA, 25-27 July 2010.

27. Schereiner, M.; Nagarajan, G. Predicting creditworthiness: Evidence from ASCRAs and ROSCAs in the Gambia. Saving Development. Q. Rev. 1997, 22, 399-413.

28. Sharma, M.; Zeller, M. Repayment performance in group-based credit programs in Bangladesh: An empirical analysis. World Dev. 1997, 25, 1731-1742. [CrossRef]

29. Doan, T.; Gibson, J.; Mark, H. What Determines Credit Participation and Credit Constraints of the Poor in Peri-Urban Areas, Vietnam? Munich Personal RePEc Archive (MPRA) Paper No. 27509; the University of Waikato: Hamilton, New Zealand, 2010. Available online: https://mpra.ub.uni-muenchen.de/27509/1/MPRA_paper_ 27509.pdf (accessed on 12 July 2019).

30. Oboh, V.U.; Kushwaha, S. Socio-economic determinants of farmers' loan size in Benue state, Nigeria. J. Appl. Sci. Res. 2009, 5, 354-358.

31. Shah, S.B.; Hashmi, A.; Bukhari, A. Determination of credit programme participation and socioeconomic characteristics of beneficiaries: Evidence from Sargodha. Pak. Inst. Dev. Econ. 2008, 47, 94.

32. Akram, W.; Hussain, Z. Agricultural credit constraints and borrowing behavior of farmers in rural Punjab. Eur. J. Sci. Res. 2008, 23, 294-304. 
33. Kedir, A. Determinants of access to credit and loan amount: Household-level evidence from urban Ethiopia. In Proceedings of the International Conference on African Development Archives, Addis Ababa, Ethiopia, 11-12 July 2003; Paper 64. Available online: http://scholarworks.wmich.edu/africancenter_icad_archive/64 (accessed on 13 September 2019).

34. Lin, L.; Wang, W.; Gan, C.; David, A.C.; Nguyen, Q. Rural Credit Constraint and Informal Rural Credit Accessibility in China. Sustainability 2019, 11, 1935. [CrossRef]

35. Sekyi, S.; Abu, B.M.; Nkegbe, P.K. Farm credit access, credit constraint and productivity in Ghana: Empirical evidence from Northern Savannah ecological zone. Agric. Financ. Rev. 2017, 77, 446-462. [CrossRef]

36. Saqib, L. Financing Agriculture through Islamic Commercial Transactions, 1st ed.; Lap Lambert Academic Publishing GMBH KG: Saarbrucken, Germany, 2011; p. 24. ISBN 3846542253.

37. Ahmadzai, H. Crop Diversification and Technical Efficiency in Afghanistan: Stochastic Frontier Analysis; Research Paper; The University of Nottingham, Centre for Research in Economic Development and International Trade (CREDIT): Nottingham, UK, 2017; No. 17/04.

38. Karlan, D.; Osman, A.; Shammout, N. To Borrow or Not to Borrow: Religious Norms and the Elasticity of Demand for Credit. Working Paper; unpublished work. 2017. Available online: www.povertyactionlab.org/sites/ default/files/publications/4267_To-Borrow-or-Not-to-Borrow_Osman-et.al_.Feb\%202017pdf.pdf (accessed on 10 December 2019).

39. Klijn, F. Informal Credit Practices in Rural Afghanistan; Case study 1: Herat; Afghanistan Research and Evaluation Unit: Kabul, Afghanistan, 2006. Available online: http://unpan1.un.org/intradoc/groups/public/ documents/apcity/unpan024222.pdf (accessed on 12 September 2019).

40. Manig, W. Formal and informal credit markets for agricultural development in developing countries-The example of Pakistan. J. Rural Stud. 1999, 6, 209-215. [CrossRef]

41. Irfan, M.; Arif, G.M.; Ali, S.M.; Nazli, H. The Structure of Informal Credit Market in Pakistan; Pakistan Institute of Develoment Economics: Islamabad, Pakistan, 1995; Research Report No. 168.

42. Rajeev, M.; Deb, S. Institutional and non-institutional credit in agriculture: Case study of Hugli district of west Bengal. Econ. Political Wkly. 1998, 33, 47-48.

43. Wang, X.; Chen, M.; He, X.; Zhang, F. Credit constraints, credit adjustment, and sustainable growth of farmers income. Sustainability 2018, 10, 4407. [CrossRef]

44. Biswas, R.K. An economic analysis of crop diversification under inorganic and organic farming in west Bengal. Int. J. Bioresour. Sci. 2016, 3, 25-30. [CrossRef] 